\title{
Putting Nepal on the Global Map of Biodiversity
}

- Dr. Tirtha Bahadur Shrestha*

The diversity and dynamism of our planet earth has created a condition to exist over 10 million of different living species and the human being (Homo sapiens) is just one of them. It took over 200 thousand years for this species to reach a population of one billion. The second billion was however added within just 100 years. In the year 1992, when the first earth summit (UN Conference on the Environment and Development) was convened, our planet was already crowded with human being reaching a record of 5 billion population within a decade after the earth summit, the $6^{\text {th }}$ billion was added. We are adding the $7^{\text {th }}$ billion in a few years time. Thus we are proceeding to a point where this planet of ours will be fully conquered and covered by human beings. There will be man and women everywhere on lands, oceans and the air. We won't see birds or butterflies, fishes or frogs, tigers or rhinoceros. They would have joined the fate of dinosaurs. Can we imagine such a world of the planet full of human beings who have sentenced all the other species to extermination and extinction? Never in the history of human evolution, the Homo sapiens have neglected to follow the path of co-existence and co-evolution with other living beings as we are witnessing today. This has to be corrected in time; one of the key environmental issues of our lifetime has become the loss of biological diversity, loss of living spaces, loss of living species, and the loss of active genetic materials where does Nepal stand in this scenario? we have to plot ourself on the global map of biological diversity.

A large number of scientists, explorers and the conservationists contributed to reveal the fact that the share of biological wealth in terms of species richness is much too big that one might have imagined for a country with just 0.1 percent of global land surfaces. We might just use the e birds and the flowering plants as our measuring rods. The regional consultation on biodiversity assessment (Shengji 1995) elucidated species richness in the countries of ICIMOD region. Nepal recorded 844 species of birds. The world wealth is accounted for just 9040 species, Nepal is claim stand at 9.33 percent. China has 1186 species i.e. $13.11 \%$, China's species wealth of birds is greater to Nepal by 1.4 times ( not ever double). On the other hand, China with an area of $9572678 \mathrm{sq}$. km. is 65 times larger than Nepal, where area is 147,181 sq. km. Similarly India (area 3287590 sq.km.) is 22.33 times larger than Nepal. India has bird wealth of 2100 species (23.23\% of world species) .That's to say it is just 2.48 times larger than Nepal. Nepali ornithologists are adding new birds through regular explorations. Nepal biodiversity Resource Book (Bhuju et al 2007) records 874 species of birds in Nepal. Global record is also enlarging as new records become available to the World Conservation Monitoring Center. In Nepal itself the Biological Profiles Project (1995) listed 11 species of birds as extinct. They existed in the $19^{\text {th }}$ and $20^{\text {th }}$ century but have now disappeared from Nepal. Three of them have been sighted recently in some protected areas (Annapurna Conservation Area, Koshi Tappu Wildlife Reserve, Makalu-Barun National Park and Chitwan National Park). However a Hornbill named after Nepal as Aceros nepalensis (Rufous-necked Hornbill) has never been reported since it disappeared from eastern Nepal. In the November of 1848 Sir Joseph Dalton Hook observed this descent hornbill in eastern Nepal. The Himalayan Journal (1885) describes his journey as following.

Though rich and fertile, the country is scantly populated, and I had much difficulty in procuring coolies; I therefore sent back to Darjiling all but indispensables and on the $9^{\text {th }}$ of November started up the ridge in the northerly direction, taking the road from llam to Wallanchoon. The ascent was gradual, through a fine forest, full of hornbills (Bureros), a bird resembling the Toucan.

The fish that escapes from the hook is always the largest. Similarly the species that goes to extinction is most precious. We must do everything to bring them back to our country. The Toucan resembling Nepal Hornbill although extinct from Nepal, is said to be fairly common in Assam (Flemming et al 1976). It is a large bird measuring $4 \mathrm{ft}(122 \mathrm{~cm})$ from beak to talil. It is larger than our Dhanesh (Giant Hornbill) according to Flemming (1976) . Similarly other extinct birds of Nepal like the Pink-headed Duck, Red-faced Liocichla, Silver-

* Life Member, Nepal Academy

The Initiation 2007 
breasted Broadbill, White-bellied Heron and the Rusty-bellied Shortwing should be brought back to Nepal through re-introduction. The Jungle Bush Quail reported by Hodpson in 1846 has not bean recorded since then. Area of Nepal also has not significantly changed since $1^{\text {st }}$ Nov. 1860 when Jung Bahadur Rana could added "new territory" (Naya Muluk) to Nepal. His census of 1860 AD (1917 B.S.) estimated human population to stand at 5200000(52 lakh). Current population estimate stands at 25 million (2 crore 50 lakh). Nepal's geography is same but Nepalese people grew to almost 5 times. The result is the loss of biodiversity.

When we examine the issue using species of flowering plants, we find Nepal equally rich. Nepal's share is over $2 \%$ of the global figure (220000 species flowering plant) and India's share is $6 \%$ i.e. 3 times greater than Nepal. Similarly Chinese flora claims about $12 \%$ of the global wealth i.e. six times greater than Nepal and not 65 times as would be evident from the territorial area. Thus Nepal is not a small country even compared with world's largest countries like China and India.

Extinction of plant species do not resound as loud as animals. Endemism in plants is much too higher than in animal kingdom. Of the 5067 species of flowering plants and gymnosperms analyzed by shrestha and Joshi (1996) 246 species are endemic to Nepal i.e.not found anywhere in the world. Of them 8 species are suspected to be extinct not only from Nepal but from the planet itself. One of them is the small orchid (Liparis clivacea) described in the year 1830. Similarly two sedge grasses (Cyperus trisuleus and C. wallichiana), one shrub (Rhus dhuna) akin to "Bhalayo", one small tree (Persea blumii) a small sun-flower (Crepis porrifolia) and a little shrub (Wardlandia appendiculata) are the species extinct from $\mathrm{Nepal}$ and the world. All those 7 species were being collected and described from Kathmandu valley betwwen $1820 \mathrm{AD}$ and $1876 \mathrm{AD}$. Most recent one is the shrubby plant (Strobilanthus tamburensis) collected from Tamor valley in 1932 AD. Thus our precious natural heritage is on decline. The need and greed of fastly growing population is threatening our biodiversity bringing down the forest coverage day by day. The episode of deforestation especially in the terai and the Bhitri Madhesh (Inner Terai) started soon after the eradication of malaria in 1960s One single species of an insect, mosquito safeguarded the biodiversity of our Terai and Madhesh. History tells that mosquito could save more rhinoceros and tigers than the military force of our government.

Government of Nepal was quick enough to heed the call of international conservationists to protect certain areas for preserving wildlife. As such the Chitwan National Park was gazetted during 1973 AD. As of to-day there are nine National Parks covering over 10,000 sq.km, as core area, and over $4,000 \mathrm{sq} . \mathrm{km}$ as their buffer zone. Similarly there are 3 wildlife Reserves covering over 2,300 sq. km. as core and 7,100 sq. km. as buffer zone. There is only one Hunting Reserve that has an area of 1,325 sq. km. Nepal pioneered to develop a new model of protected area and created conservation areas where local people are responsible for nature conservation and also for sustainable use of its resources. As such there are 3 conservation areas that cover 11,300 sq.km. Thus Nepal's protected area system adds to 35,432 sq. $\mathrm{km}$. Which works out to be 24.07 percent of her territory. Is it enough? Is it the best way? There is no one answer? New models are being tried and practiced. Conservationists now look for landscape level management system become the fear looms that isolated pockets of protected areas follow a process of degradation if the rest of the landscape is let to deteriorate.

The convention of biological diversity which was adopted during the Earth Summit 1992 sets out three basic objectives i.e. conservation, sustainable use, and the fair and equitable sharing of benefits, The irony for biodiversity rich countries like Nepal is that they are economically poor and technologically still poorer and weak. Therefore the fair and equitable sharing of benefits especially with industrialized country remains to be a far fetched dream. Sharing the benefits of coca cola with the people of South American Peruvian coca country or such as Peru with the coca countries in Africa would need a new and revolutionary mechanism in the world trade. Economic benefits from the use of our traditional medicine Sarpagandha (Rauwolfia serpentiana) is treating patients of schizophrenia ,blood-pressure and various mental disorders through modern allopathic medicine amount to multi-millions of dollar. Benefit sharing mechanism between countries of origin (Asia) and countries of drug development industries (Europe and USA) has not yet been developed or even 
conceived . The concept of benefit sharing should be examined in context of north-south cooperation and collaboration to arrive at a meaningful conservation of biodiversity for a safe journey of humankind through the $21^{\text {st }}$ century.

\section{Reference:}

Bhuju, U.R., Shakya, P.R., Basnet, T.B. and Shrestha S. (2007); Nepal Biodiversity Resource Book- Protected Areas, Ramsar Sites and World Heritage Sites, ICIMOD/MOESTGON/Nepalnature.com/UNEP, Kathmandu

Shengji, P.(et) (1995); Banking on Biodiversity -Report on the Regional Consultation on Biodiversity Assessment in the Hindukush-Himalaya, ICIMOD, Kathmandu

Hooker, J.D. (1855); Himalayan Journals, $4^{\text {th }}$ Indian Reprint 1987, Today and Tommorrow's Printers and Publishers, New Delhi

HMGN/MOFSC (2002); Nepal Biodiversity Strategy, GEF/UNDP/HMG, Kathmandu

Shrestha T.B. (1999); Nepal Country Report on Biological Diversity , IUCN-Nepal , Kathmandu

Fleming , R.L. Sr and Jr and Bangdel , L.S.(1976) ; Birds of Nepal-with Reference to Kasmir and Sikkim, Published by Robert L. Fleming, Sr and Jr. Kathmandu, Nepal

IUCN-Nepal (2005); Nepal's Illustrated Biodiversity Primer, IUCN-Nepal

Shrestha T.B. and Joshi R.H.(1996), Rare, Endemic and Endangered Plants of Nepal, WWFNepal Program, Kathmandu

Wilson, E.O.Ed (1988); Biodiversity, National Academic Press, Washington D.C

BPP, (1995) Red Data Book of the Fauna of Nepal, Biodiversity Profiles Project, Publication No.4, DNPWC/MFSC/HMG, Nepal

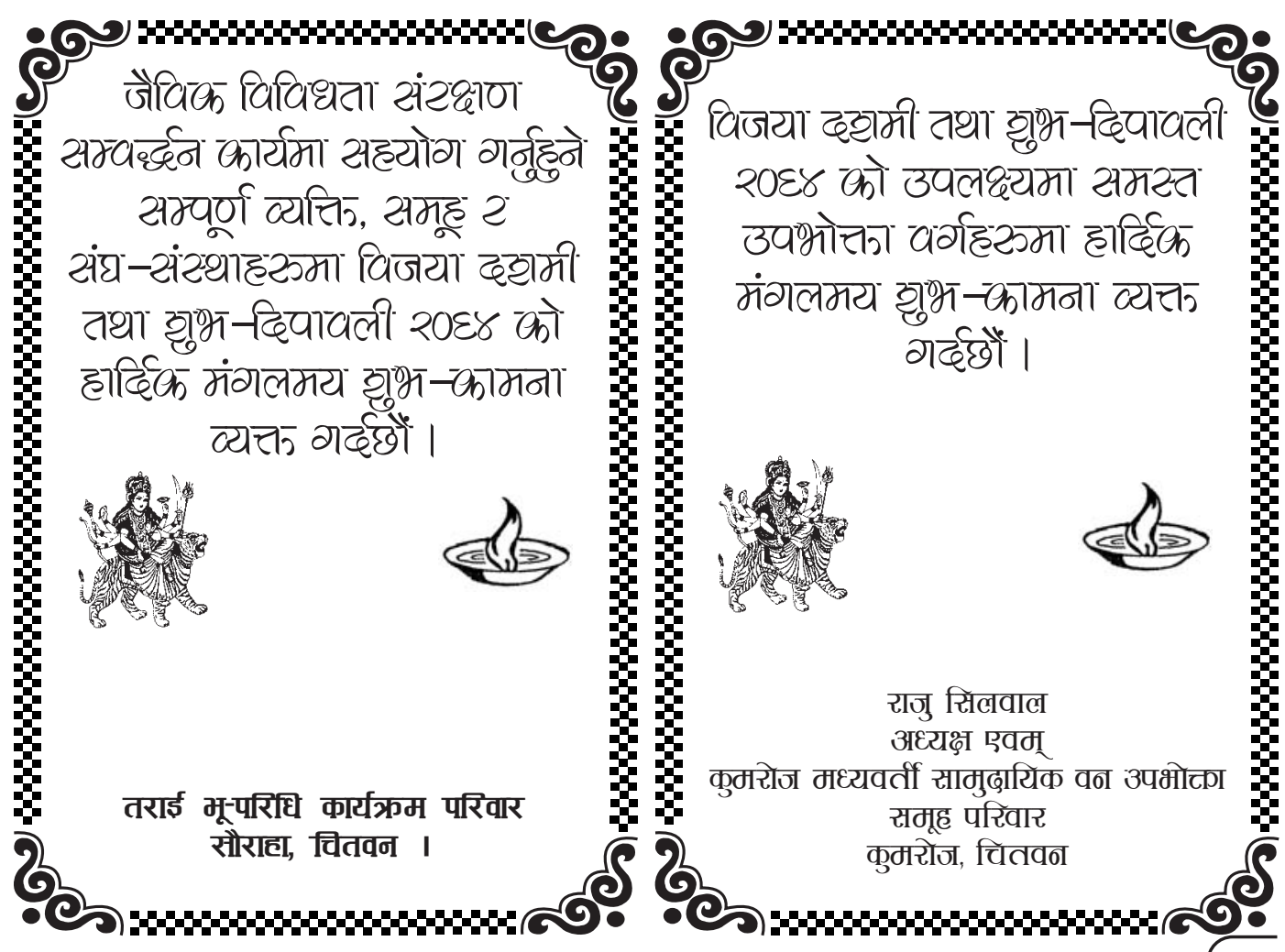

The Initiation 2007003 